\title{
Introduction Test Edible Coating Fresh Fish Fillet of Tuna and Smoked Fish Using Biopolymer Nanoparticle Chitosan Coconut Crab
}

\author{
Hamidin Rasulu ${ }^{1, *}$, Danar Praseptiangga ${ }^{2}$, I Made Joni ${ }^{3,4}$, Ari Handono Ramelan ${ }^{5}$ \\ ${ }^{1}$ Department of Food Technology, Faculty of Agriculture, Khairun University, Ternate, Indonesia \\ ${ }^{2}$ Department of Food Science and Technology, Faculty of Agriculture, Sebelas Maret University, Surakarta, Indonesia \\ ${ }^{3}$ Nanotechnology and Graphene Research Center, Universitas Padjadjaran, Jatinangor, Indonesia \\ ${ }^{4}$ Department of Physics, Faculty of Mathematics and Natural Sciences, Universitas Padjadjaran, Bandung, Indonesia \\ ${ }^{5}$ Department of Physics, Faculty of Mathematics and Natural Sciences, Sebelas Maret University, Surakarta, Indonesia \\ *Corresponding author. Email: hamidinrasulu@yahoo.com
}

\begin{abstract}
Maintaining the quality of fish can be done in several ways among others by utilizing the edible packaging technology. The use of chitosan biopolymers in the form of chitosan nanoparticles to maintain the quality of fresh skipjack fish and smoked tuna is the best solution to avoid the use of synthetic compounds. The purpose of this research is to examine the utilization of the biopolymer material of nanoparticles chitosan coconut crab (NPs CsCC) of the beads-milling method as a natural preservative and antibacterial on the manufacture of edible fish-coating tuna fresh fillet and smoked tuna fish. Results showed that the use of chitosan nanoparticles as an edible coating can serve as active packaging and able to maintain the quality of fishery products. This is evident from the formula of using the concentration of nanoparticles chitosan coconut crab (NPs CsCC) and the duration of observations as follows; The addition of $2(\% \mathrm{w} / \mathrm{v})$ nanoparticles in a fresh tuna coating fish fillet can meet SNI standard (12 hours observation time). The addition of $3(\% \mathrm{w} / \mathrm{v})$ nanoparticles on the fish coating in filet smoked tuna can meet SNI standard (observation time 72 hours).
\end{abstract}

Keywords: edible coating, nanoparticles, chitosan, coconut crab, tuna fish, fufu

\section{INTRODUCTION}

The freshness level of fish is very important to note because it is easily damaged. The deterioration of the quality of fish that is fast after the dead fish is caused by several factors such as the process of enzymatic or a microorganism that develops in the body of fish. The biochemical changes and post-harvest microbes in the fish tissue depend significantly on the factors that control the concentration of substrates and the metabolites associated with microbial contamination and after-arrest conditions $[1]$.

The perfect packaging material should not move any harmful molecule from packaging material into the product. To maintain the quality of fish can be done in several ways among others by utilizing the edible packaging technology. Edible coating and edible film, as well as a biodegradable material, offer alternative packaging systems that may replace some of the packaging material synthesis or reduce the use of synthetic materials [2]. Various studies have shown that film and edible coating can serve as a carrier of food additives, such as anti-browning agents, antimicrobial, dyes, flavor givers, nutrients and seasonings $[3,4]$.

The use of natural materials in the packaging of edible made from natural polymer will reduce plastic waste derived from polymer synthesis thereby reducing environmental damage. Therefore, chitosan is a polymer compound produced from the extraction of hard to do animals/crustaceans. Besides polymer chitosan has easily degraded properties of biological degradation, not toxic, is a strong cation, good coagulants and easily forms a membrane or film. Further mixing of chitosan into composites will further enhance its characteristics in addition to cost efficiencies [5]. In addition to the use of chitosan in the form of nanoparticles (nano-chitosan) to improve the shelf life of newly captured young yellow tuna [6].

Based on such information, the influence of nanoparticle polymer chitosan coconut crab (NPs CsCC) to the characteristics of fresh tuna fish and smoked tuna (fufu) became very interesting to do research. In the future, the use of this polymer as a natural ingredient is expected to be applied to food packaging, especially in the edible film and edible coatings that are safe to use to extend the shelf life of the fish. The purpose of this research is to examine the utilization of biopolymer materials of NPs CsCC the results of beads-milling method as a natural preservative and antibacterial on the manufacture of edible coated fresh tuna fish and smoked tuna (fufu). 


\section{MATERIALS AND METHOD}

\subsection{Materials}

The materials used in this study are biopolymer chitosan coconut crab (CSCC) and biopolymer nanoparticle chitosan coconut crab (NPS CsCC) the results of the beads-milling method (DD 89\%). Fresh skipjack tuna (obtained from fishermen catch daily in Ternate city) and smoked tuna (obtained from the craftsmen from Ternate city).

\subsection{Research procedures}

\section{A. Edible Coating on fresh Tuna fish fillet}

The manufacture of a coating solution as a preservation process in fresh tuna is with the use of a biopolymer of chitosan nanoparticles (NPs CsCC) beads-milling method. Coating making is dissolve NPS CsCC suspension (1, 2, 3 $(\% \mathrm{w} / \mathrm{v})$ and Chitosan CC $1(\% \mathrm{w} / \mathrm{v})$ into the $100 \mathrm{ml}$ aquadest. Use the hot plate magnetic stirrer $60{ }^{\circ} \mathrm{C}$ for 15 minutes, $350 \mathrm{rpm}$, until a homogeneous solution. Then add glycerol $1 \mathrm{ml}$ into the solution as a plasticizer. Prepare the fresh tuna fish fillet with a size of $6 \times 4 \mathrm{~cm}$. Next, the fresh tuna fish fillet is dipped in a suspension coating solution made by NPs CsCC. Dyeing is done for 2 minutes with 2 repeats. The Fillet of tuna that has been coated by edible coating is then stretched and stored for 24,48 hours at room temperature $\left( \pm 27{ }^{\circ} \mathrm{C}\right)[7]$.

\section{B. Edible Coating on Tuna Smoked Fish (Fufu)}

The procedure of making a coating solution on smoked tuna (fufu) is by using the suspension of chitosan nanoparticles (NPs CsCC). The initial stage was to dissolve the NPS CSCC suspension into the $100 \mathrm{ml}$ of the aquadest respectively $0,1,2,3(\% \mathrm{w} / \mathrm{v})$ and chitosan CC 1 $(\% \mathrm{w} / \mathrm{v})$, heat and homogenize using a magnetic stirrer 60 ${ }^{0} \mathrm{C}$ for 15 minutes, $350 \mathrm{rpm}$, a homogeneous solution. Then add the glycerol into the solution as a plasticizer with a concentration of $1 \mathrm{ml} \mathrm{(v/v)} \mathrm{stir} \mathrm{for} \mathrm{5-10} \mathrm{minutes.} \mathrm{Prepare}$ the fish tuna (fufu) size $6 \times 4 \mathrm{~cm}$, next to the bonito smoked tuna (fufu) dipped in a solution of edible coating chitosan nanoparticles. Dyeing is done for 2 minutes with 2 repeats, then for 10 minutes and the storage process is in the room temperature conditions $\left( \pm 27{ }^{\circ} \mathrm{C}\right)$ with a variation of storage time 24, 48, and 72 hours [7].

Variable testing samples of fresh skipjack tuna fish and smoked tuna (fufu) by the coating of polymer nanoparticles of chitosan $\mathrm{CC}$ from each concentration conducted microbiological Test determination: TPC (Total Plate Count). Biochemical test: $\mathrm{pH}$, Total Volatile Base (TVB), and organoleptic test: color, elasticity and flavor.

\section{3. $\mathrm{pH}$ measurements}

Measurement of $\mathrm{pH}$ sample value edible coating fish tuna fillet and smoked fish (fufu) using NPs CsCC suspension biopolymer with $\mathrm{pH}$ meter tool. The $\mathrm{pH}$ meter device is calibrated first with a buffer solution at $\mathrm{pH} 4$ and 7 .

\subsection{Number of bacterial colonies}

In microbiological trials on the number of bacterial colonies used TPC analysis determination (Total Plate
Count) sample of edible coating of tuna fish fillet and tuna smoked fish (fufu) using NPs CsCC suspension biopolymer. The working principle of TPC analysis is calculation of the number of bacterial colonies that are in the sample (fish meat) with dilution as needed and done for preliminary research triplo and at stage three done in a duplo. The manufacture of sample solution by mixing 5 grams of samples into $45 \mathrm{ml}$ of the diluent solution so that obtained dilution 10-1 (1:10). Furthermore, there is a successive dilution of 10-2 and onwards as needed. Sampling and fertilization are done aseptically. The media agar (sodium agar) is fed into the petri dish as much as 10 $\mathrm{ml}$ and wiggles to the surface to be evenly distributed (pouring cup method), then allowed some time to cool and solidify. Petri dish that has been contained in the order and sample solution inserted into the incubator with the reverse position, the cup lid is placed at the bottom of the petri dish. The incubator temperature used is about $30{ }^{\circ} \mathrm{C}$ and incubated for 2 days, then observed by counting the number of colonies in the petri dish.

\subsection{Total Volatile Bases Analysis (TVB)}

TVB is one of the parameters to determine the deterioration of fish quality. This determination aims to determine the amount of volatile compounds bases formed due to protein degradation. The principle of TVB analysis is to vaporize the volatile base compounds (ammonia, mono-, di-and Trimethylamine). Samples of edible coating of tuna fish fillet and tuna smoked fish (fufu) use NPs $\mathrm{CsCC}$ suspension polymer. The compound is then tied by boric acid and then it is then assigned with a solution of HCL 0.02 N. Sample of the meat of skipjack fish as much as $25 \mathrm{~g}$ in Add $75 \mathrm{ml}$ of TCA $7.5 \%$ solution blended for 2 minutes and then filtered with paper so that the filtrate obtained in clear color. A solution of $1 \mathrm{ml}$ of boric acid is inserted into the "inner chamber" cup of the conway and placed the lid of the cup with a position almost covering the cup. Using another $1 \mathrm{ml}$ pipette, the filtrate is inserted into the outer chamber on the left. It is then added $1 \mathrm{ml}$ of $\mathrm{K}_{2} \mathrm{CO}_{3}$ saturated into the right outer chamber so that filtrate and $\mathrm{K}_{2} \mathrm{CO}_{3}$ are not mixed. In addition, the cup was immediately closed and moved to play until the two liquids in the outer chamber mixed. Besides, it is done with the same procedure but filtrate replaced by TCA 7.5\% solution. Then the two cups of conway were kept in incubators at $35{ }^{0} \mathrm{C}$ for 2 hours. Once stored, the solution of boric acid in the inner chamber of the Conway Cup containing blanko is held in a solution of $\mathrm{HCl} 0.02 \mathrm{~N}$ (Vo), using a volumetric pipette so that it turns pink. Then the cup of conway contains the same solution until the same pink color as blanko $(\mathrm{Vi})$.

Levels TVB $=(j-j) \times N ~ H C l \times 100 \times \underline{f p} \times 14 \mathrm{mg} \mathrm{N} / 100 \mathrm{~g}$

$$
\text { M } 1
$$

\section{Organoleptic Test}

Organoleptic testing is a subjective testing way by using the human senses as the primary tool for the acceptance of feeding power. The purpose of this organoleptic test is to determine the quality of fish packaged in an edible coating 
in terms of color, elasticity, and flavor. The number of people included in each test period is 20 untrained panelists [8]. Where each study was asked to respond privately to his own favorite.

\section{Data Analysis}

The Data obtained is analyzed using SPSS 24 software. The analysis used is ANOVA if there is an influence of treatment, conducted a test of DMRT $(\mathrm{P} .<0.05)$.

\section{RESULTS AND DISCUSSION}

\subsection{Microbiological Test Result and Biochemical Test of Fresh Tuna Fish}

\subsubsection{Total Plate Count (TPC)}

The degree of damage to fishery products is analyzed using TPC analysis methods, namely microbiological damage, depending on the speed of microbial growth of the decay bacteria. In table 1 indicates that the results of TPC analysis on the process edible coating of fresh s tuna fish by using the concentration of NPs CsCC polymer 1, 2, $3,4(\% \mathrm{w} / \mathrm{v})$ and $\mathrm{CsCC} 1$ (\%w.v), the average value of fresh tuna fish with an observation time of 12 hours (K-12) respectively $3.25-5.25 \operatorname{logs}$ CFU meanwhile, the average value of 24-hour observation $(\mathrm{K}-24)$ is $5.15-7.25 \mathrm{logs}$ $\mathrm{CFU} / \mathrm{gram}$. The result of variegated analysis $(\alpha=0.05)$ on the TPC value indicates that the NPs CsCC concentration during storage of 12 and 24 hours gives a noticeable effect on the value of TPC on fresh skipjack fish, while the concentration of $\mathrm{CsCC} 1 \%$ on the length of 12 and 24 hours of storage does not give a significant effect as it exceeds the TPC quality standard in fish with SNI 012733.1-2006 of 5.0 x 105 Colony/gram or 5.7 logs $\mathrm{CFU} / \mathrm{gram}$. Therefore the results of the real difference test show that TPC value at each concentration of NPs CsCC and $\mathrm{CsCC} 1 \%$ differs from each other.

Table 1. TPC, TVB, and $\mathrm{pH}$ values on edible coating of fresh tuna fish (KS) with biopolymer concentration of NPs CsCC

\begin{tabular}{|c|c|c|l|l|}
\hline $\begin{array}{c}\text { Fresh Fish Fillet } \\
\text { Observation } \\
\text { (hours) }\end{array}$ & $\begin{array}{c}\text { Concentratio } \\
\text { n of CsCC } \\
\text { NPs (\%) }\end{array}$ & $\begin{array}{c}\text { TPC value (log } \\
\text { CFU/gr) }\end{array}$ & $\begin{array}{c}\text { TVB value } \\
\left.\mathbf{( m g}^{\mathbf{N}} / \mathbf{1 0 0} \mathbf{g}\right)\end{array}$ & pH value \\
\hline \multirow{4}{*}{ KS_12 } & 1 & $4.25 \pm 0.35 \mathrm{~B}$ & $10.20 \pm 0.21 \mathrm{D}$ & $4.25 \pm 0.35 \mathrm{~B}$ \\
\cline { 2 - 5 } & 2 & $3.50 \pm 0.71 \mathrm{C}$ & $12.34 \pm 0.53 \mathrm{C}$ & $4.25 \pm 0.35 \mathrm{~B}$ \\
\cline { 2 - 5 } & 3 & $3.25 \pm 0.35 \mathrm{C}$ & $16.02 \pm 1.07 \mathrm{~A}$ & $5.25 \pm 0.30 \mathrm{~A}$ \\
\cline { 2 - 5 } & $\mathrm{CsCC} 1 \%$ & $5.25 \pm 0.35 \mathrm{~A}$ & $13.49 \pm 0.52 \mathrm{~B}$ & $4.25 \pm 0.35 \mathrm{~B}$ \\
\hline \multirow{4}{*}{ KS_24 } & 1 & $6.50 \pm 0.71 \mathrm{~B}$ & $22.65 \pm 0.27 \mathrm{D}$ & $4.75 \pm 0.25 \mathrm{C}$ \\
\cline { 2 - 5 } & 2 & $5.75 \pm 0.35 \mathrm{C}$ & $25.29 \pm 0.35 \mathrm{C}$ & $5.25 \pm 0.30 \mathrm{~B}$ \\
\cline { 2 - 5 } & 3 & $5.15 \pm 0.12 \mathrm{D}$ & $31.26 \pm 0.16 \mathrm{~A}$ & $5.75 \pm 0.25 \mathrm{~A}$ \\
\cline { 2 - 5 } & CsCC $1 \%$ & $7.25 \pm 0.35 \mathrm{~A}$ & $27.60 \pm 0.49 \mathrm{~B}$ & $4.75 \pm 0.25 \mathrm{C}$ \\
\hline
\end{tabular}

The values followed by the same letter are not distinct from each other $(\alpha=0.05)$.

Table 2. The favorite level of edible fish tuna fresh fillet with biopolymer concentration NPs CsCC

\begin{tabular}{|c|c|c|c|c|}
\hline $\begin{array}{c}\text { Fresh Fish Fillet } \\
\text { Observation } \\
\text { (hours) }\end{array}$ & \multirow{2}{*}{$\begin{array}{c}\text { Concentration of } \\
\text { CsCC NPs (\%) }\end{array}$} & Color & Elasticity & Flavor \\
\cline { 2 - 5 } & 1 & $5.00 \pm 1.17 \mathrm{~A}$ & $5.40 \pm 0.88 \mathrm{~A}$ & $4.80 \pm 1.36 \mathrm{~A}$ \\
\cline { 2 - 5 } & 2 & $4.65 \pm 0.99 \mathrm{~A}$ & $4.85 \pm 0.93 \mathrm{~A}$ & $4.50 \pm 1.19 \mathrm{~A}$ \\
\cline { 2 - 5 } & 3 & $4.60 \pm 1.23 \mathrm{~A}$ & $4.70 \pm 1.03 \mathrm{~A}$ & $4.50 \pm 1.24 \mathrm{~A}$ \\
\cline { 2 - 5 } & CsCC 1\% & $4.35 \pm 1.27 \mathrm{~A}$ & $4.25 \pm 1,21 \mathrm{~A}$ & $3.95 \pm 1.32 \mathrm{~A}$ \\
\hline \multirow{3}{*}{ KS_24 } & 1 & $2.50 \pm 1.36 \mathrm{~A}$ & $3.60 \pm 1.57 \mathrm{~A}$ & $2.70 \pm 1.42 \mathrm{~A}$ \\
\cline { 2 - 5 } & 2 & $3.00 \pm 1.03 \mathrm{~A}$ & $4.00 \pm 1.45 \mathrm{~A}$ & $2.95 \pm 1.05 \mathrm{~A}$ \\
\cline { 2 - 5 } & 3 & $2.95 \pm 1.28 \mathrm{~A}$ & $3.85 \pm 1.09 \mathrm{~A}$ & $3.10 \pm 1.12 \mathrm{~A}$ \\
\cline { 2 - 5 } & CsCC 1\% & $2.90 \pm 1.07 \mathrm{~A}$ & $3.10 \pm 1.12 \mathrm{~A}$ & $2.80 \pm 0.62 \mathrm{~A}$ \\
\hline
\end{tabular}

The values followed by the same letter are not distinct from each other $(\alpha=0.05)$

TPC value of fresh tuna fillet on the 12-hour storage observation $(\mathrm{K}-12)$ is the lowest at the NPs CsCC 3\% concentration and $2 \%$ which are significantly different from the $1 \%$ NPs CsCC concentration as well as the CsCC $1 \%$ (Table 1). This indicates that the use of a polymer nanoparticle chitosan $\mathrm{CC}$ as antimicrobial material on the 
manufacture of edible coating is very effective when compared with the use of CsCC polymer $1 \%$ only. The higher the concentration of NPs CsCC will increase the effectiveness of the nanoparticles of chitosan in inhibiting bacterial growth. This is due to the increased concentration of each treatment, the viscosity properties will be increased so that the chitosan will be more easily diffused in the media in order to [9]. Earlier researchers showed that nano-chitosan was quite effective at low concentrations in fish preservation at a storage condition of $28{ }^{0} \mathrm{C}[6]$.

One method to see the freshness of the fish is by TPC analysis. The working principle of TPC analysis is the calculation of the number of bacterial colonies present in the sample (tuna fish fillets) with dilution as needed and performed in duplo [10]. Therefore the ability in the process of inhibition of damage level in fresh fish using NPs CsCC biopolymer with a variety of concentrations is very effective when compared to only using $\mathrm{CsCC}$ in inhibiting the growth of bacteria especially the Pseudomonas aeruginosa group and bacillus cereus (Table 1). Although in the use of chitosan (CsCC 1\%) On edible coating of fresh tuna fish can also inhibit the growth of bacteria with the value of TPC low 4.93 logs CFU/gram. This is reinforced by the results of the use of chitosan $1.5 \%$ capable of inhibiting the growth of bacteria in the edible coating of patin fish at room temperature storage $[11,7]$.

\subsubsection{Total Volatile Base (TVB)}

The measurement of TVB value in fresh tuna fish is done to know the level of freshness which in principle vaporizes volatile compounds such as ammonia, trimethyl amin and dimethyl amin that exist in the sample of fresh tuna fillet fish. In Table 1 indicates that the use of the NPs CsCC biopolymer concentration with long observation time during storage takes place on 12 and 24 hours with a suspension concentration of NPS CsCC and chitosan suspension pure $\mathrm{CC}$ for samples of $\mathrm{K}-12$ respectively $10.20-16.02 \mathrm{mg} \mathrm{N} / 100 \mathrm{~g}$, as well as for the sample K-24 respectively $22.65-31.26 \mathrm{mg} \mathrm{N} / 100 \mathrm{~g}$.

Results of the analysis of TVB value of fresh tuna fillet showed that the NPs CsCC biopolymer in the edible coating formula has a real effect on the value of TVB. A few times the increase in the value of TVB fresh tuna fish during the storage period of K-24 observation is due to the breakdown of complex macromolecular compounds into simpler volatile compounds. Fish damage is measured based on the value of TVB with the use of different nanochitosan significantly able to suppress bacterial activity, but not able to reduce the number of bacteria in the conditions of space temperature storage $\left(28{ }^{0} \mathrm{C}\right)[6]$.

While further testing $(\alpha=0.05)$ on the length of storage and concentration of polymer NPs CsCC TVB K-12 values decreased at concentrations of $1 \%$ and $2 \%$, as well as the use of CsCC $1 \%$ also decreased. While the $3 \%$ concentration has increased. The same with the value of TVB K-24 which greatly increased significantly the increase compared to the value of TVB K-12. This is due to the high value of TVB on fresh skipjack tuna fish allegedly due to high water content and the number of microbes from each treatment with different concentrations. Therefore, the high water content in foodstuffs, resulting in a microbiological protein change process produces more simple nitrogen compounds and is a substrate for the growth of microorganisms, thereby accelerating the decay process [12]. In addition, the use of chitosan suspension $0.1 \%$ as an edible coating on the Presto milkfish during the space temperature storage period, indicating that the shelf life increased 16-38 hours with the value of TVB and TPC will increase after 72 storage hours [13]. Similarly, the level of TVB increases during storage as it increases the number of microbes that break down protein and nitrogen-containing compounds for growth. Increased microbial count growth results in more and more volatile, nitrogen-based compounds that are formed and measured as volatile bases [14]

\subsection{3. $\mathrm{pH}$}

The measurement of acidity level by determining the $\mathrm{pH}$ value of fresh skipjack tuna fish using NPs CsCC polymer with different concentrations with different length of observation can produce the average $\mathrm{pH}$ value for the duration of 12 hour observation $(\mathrm{K}-12)$ has a value of each $4.25-5.25$. While the 12-hour observation (K-12) has a value of $5.75-4.75$ respectively. The results of the printing $(\alpha=0.05)$ of the $\mathrm{pH}$ value of the fresh skipjack tuna fish show that the addition of NPs CsCC suspension biopolymer in the edible coating formula affects the $\mathrm{pH}$ value. While further testing shows that on long observations during storage of $\mathrm{K}-12$ and $\mathrm{K}-24$ at room temperature, the $\mathrm{pH}$ value of the fresh tuna fish are given the edible coating of NPs CsCC 2 and 3 (\% w/v) suspension with a different length of observation than higher $\mathrm{pH}$ values compared to the use of NPs CsCC with a concentration of $1(\% \mathrm{w} / \mathrm{v})$ and the use of polymer suspension CsCC 1\% has a lower $\mathrm{pH}$ value (Table 1 )

This is due to the presence of polymer chitosan in production into NPs CsCC with the method of beadsmilling in an edible coating formula that helps inhibit the growth of lactic acid bacteria and maintain the $\mathrm{pH}$ value of fresh tuna fish. The results of previous research using edible coating treatment of chitosan are absolutely noticeable in the increase of $\mathrm{pH}$ value by increasing the length of storage from $\mathrm{pH} 5$ to 5.65 [7].

\subsubsection{Color}

The main characteristic of the sensory assessment conducted by consumers in choosing a product is color [15]. Based on the results of hedonic test (favorite level) conducted by the untrained panelist, showed that the use of edible coating with the basic biopolymer NPs CsCC with a certain concentration and the length of storage of different observation times on the fresh tuna fish has an average value level of preference to color (Table 2). Based on the results of sensory testing of fresh tuna fish, has the average value of color in the observation K-12, respectively 4.35 (somewhat fond) -5.00 (likes), while the level of 
preference on observations $\mathrm{K}-24$, respectively 2.50 (somewhat dislikes) -3.00 (somewhat dislikes).

The results of the prints $(\alpha=0.05)$ of the color value of the fresh tuna fish indicates that the edible coating treatment made from biopolymer NPs CsCC with different concentrations and long observations during different storage has no real effect on the color value of the fresh tuna fillet fish both at the observation period of 12 hours and 24 hours. This is due to the main ingredient properties of skipjack tuna which is easy to experience changes in physical properties and the presence of microbial contamination that causes discoloration in fresh tuna fish products. But for observation on the length of storage K12 at concentrations 2 and $3(\% \mathrm{w} / \mathrm{v})$ The favorite level of panelist is still high enough each $4.60-4.65$ (like), meaning that the influence of the addition of Biopolymer NPs CsCC can inhibit physical change in fresh skipjack tuna fish, as well as a TPC test that shows low levels of bacterial colonies in both .

The antimicrobial component contained in the edible coating made from biopolymer NPS $\mathrm{C}_{\mathrm{S}} \mathrm{CC}$ and chitosan $\mathrm{CC}$ has not been able to retain the color of fresh skipjack tuna fish during the observation period on 12 and 24-hour storage. There are some things that cause discoloration in fish other than storage time, fish raw material that is easily damaged, as well as the mechanical process in the handling of materials is the process of dying fish on the suspension NPs CsCC that has a different time vulnerable and the provision of heat in each biopolymer NPs CsCC. Duration of storage, quality parameters such as elasticity, color, taste and so on will change due to environmental influences such as temperature, humidity the food composition factor itself [7].

\subsubsection{Elasticity}

The sensory test assessment for the elasticity parameter is done to measure the hard and soft meat of the fresh skipjack tuna fish performed by panelists. Based on the results of hedonic test (favorite level) conducted by the untrained panelist, showed that the use of edible coating with the basic biopolymer NPs CsCC with a certain concentration and long storage of different observation times on the fresh tuna fish has the average value of your favorite levels of elasticity (Table 2). Based on the results of sensory testing of fresh skipjack tuna fish, have an average value of elasticity in the observation $\mathrm{K}-12$, respectively 4.25 (somewhat fond) - 5.40 (likes), while the level of preference on observation K-24, respectively 3.10 (somewhat dislikes) - 4.00 (somewhat like).

The results of the printing $(\alpha=0.05)$ against the value of the elasticity of the fresh tuna fish showed that the edible coating treatment made from biopolymer NPs CsCC with different concentrations and long observations during different storage has no effect real value of the elasticity of the fresh fish tuna fillet both at the observation period of 12 hours and 24 hours. This is caused by the main ingredient properties of tuna that easily undergo changes in the physical properties that cause the change of elasticity to be softer in the product of fresh tuna.
The antimicrobial component contained in the edible coating made from biopolymer NPs CsCC and chitosan $\mathrm{CC}$ has not been able to maintain the elasticity of fresh tuna fish during the observation period on 12 and 24-hour storage. The use of NPS CsCC biopolymers and CC chitosan suspension can inhibit fish decay so as to maintain the meat's elasticity during storage. The decay process is known to cause the meat's elasticity to be malleable. The changes in the elasticity can also be caused by the breakdown of the fish meat tissue structure. Tissue damage is caused by biochemical changes and microbial activity so there is no power to prop up the structure of the flesh with a compact [7].

\subsubsection{Flavor}

The characteristic flavor assessment is done by a panelist on food products aimed at assessing the favorite level of aroma and smell components in the meat of fresh tuna fish. Based on the results of the hedonic test (favorite level) conducted by the untrained panelist, indicating that the use of edible coating with biopolymer-based NPs CsCC with a certain concentration and the length of storage of different observations on the fresh tuna fish has an average value of the favorite levels of flavor (Table 2). Based on the results of sensory testing of fresh tuna fish, have the average value of the fruit of the K-12 observation, 3.95 (somewhat fond) -4.80 (like), while the favorite level on the observation K-24, respectively 2.70 (somewhat dislikes) 3.10 (somewhat dislikes).

The results of the printing $(\alpha=0.05)$ of the flavor value of the fresh tuna fillet showed that the edible coating is made from the biopolymer NPs CsCC with different concentrations and long observations during different storage has no real effect on the value of fresh fish flavor good at the observation period of 12 hours and 24 hours. This is caused by the main ingredient properties of tuna that easily undergo changes in chemical properties that cause flavor change to decline in the product of fresh tuna fish. The antimicrobial component contained in the edible coating made from biopolymer NPs CsCC and chitosan $\mathrm{CC}$ has not been able to maintain the flavor of fresh tuna fish during the observation period on 12 and 24-hour storage. This occurs in line with the increase in the level of TVB in fresh tuna using the different concentrations of NPs CsCC biopolymers. Suspected decomposition of the chemical components of fish products. Therefore, the change of foul smell arising in the process of deterioration of the quality of tuna is a result of the activity of proteolytic microorganisms that describe proteins into compounds that smell like hydrogen sulfide, Indol and others [7].

\subsection{Microbiological test result and Biochemichal test of tuna (Fufu)}

\subsubsection{Total Plate Count (TPC)}

Decrease in the quality of fishery products characterized by the occurrence of damage to physical and chemical characteristics and organoleptic in tuna smoked fish (fufu), 
it is necessary to do preliminary testing microbiological using TPC analysis method with the treatment of different concentrations of biopolymer NPs CsCC and CsCC, namely microbiological damage caused by microbial growth rate is bacteria decay. In Table 3 indicates that the results of TPC analysis on the process of edible fish smoked tuna using polymer concentrations NPs CsCC 0 , $1,2,3(\% \mathrm{w} / \mathrm{v})$ and $\mathrm{CsCC} 1 \%$, the average value of tuna fumes with 24 hour observation time (KA-24) respectively is $1.18-3.15 \log \mathrm{CFU} /$ gram. While the median value of observations of 48 hours (KA-48) respectively is $3.32-$ 4.75 CFU/gram logs. Furthermore, the median value of observations of 72 hours (KA-72) respectively is $3.92-$ $6.58 \log \mathrm{CFU} / \mathrm{gram}$. The results of the analysis of the variety $(\alpha=0.05)$ on the value of TPC shows that the NPs CsCC concentration and CsCC concentration of $1 \%$ during storage 24, 48 and 72 hours give a real influence on the value of TPC in the smoked tuna because it does not exceed the quality standards of TPC in fish with SNI 012733.1 -2006 maximum of $5.0 \times 105$ colony/5.7 gram.

In Table 3 TPC values look increasingly higher concentrations of NPs CsCC will increase the effectiveness of nanoparticles of chitosan in inhibiting the growth of bacteria in the smoked tuna. This is due to the increased concentration of each treatment, the viscosity properties will be increased so that the chitosan will be more easily diffused in the media in order to [9].

\subsubsection{Total Volatile Base (TVB)}

The measurement of TVB value on smoked skipjack tuna is done to know the level of freshness which in principle vaporizes volatile compounds such as ammonia, trimethyl amin and dimethyl amin in the sample of tuna smoked fish (fufu). In Table 3 shows that the results of TPC analysis of edible coating of tuna with the use of biopolymer concentrations of NPs CsCC 0, 1, 2, 3 (\% w/v) and CsCC $1 \%$, the average value of tuna smoked fish with 24 hour observation time (KA-24) each is $6.11-8.33 \mathrm{mg} \mathrm{N} / 100 \mathrm{~g}$. While the median value of observations of 48 hours (KA48) respectively is $8.29-10.55 \mathrm{mg} \mathrm{N} / 100 \mathrm{~g}$. Furthermore, the average value of the observations of 72 hours (KA-72) respectively is $9.62-12.64 \mathrm{mg} \mathrm{N} / 100 \mathrm{~g}$. Results of the analysis of variance $(\alpha=0.05)$ against the TPC value indicate that the NPs CsCC concentration and $\mathrm{CsCC}$ concentration of $1 \%$ during storage of 24,48 and 72 hours give a noticeable impact on TPC value to the smoked tuna. This is due to the high value of TVB in smoked tuna (fufu) allegedly due to high water content and the amount of microbes from each treatment with different concentrations. Therefore, the high water content in foodstuffs, resulting in a microbiological protein change process produces more simple nitrogen compounds and is a substrate for the growth of microorganisms, thereby accelerating the decay process [12-13]..

Table 3. Value TPC, TVB, $\mathrm{pH}$ edible coating tuna smoked fish (KA) using chitosan nanoparticle concentration with long storage time

\begin{tabular}{|c|c|c|c|c|}
\hline $\begin{array}{c}\text { Length of storage } \\
\text { (hours) }\end{array}$ & $\begin{array}{c}\text { Concentration of } \\
\text { CsCC NPs (\%) }\end{array}$ & $\begin{array}{c}\text { TPC velue } \\
\text { (log CFU/gr) }\end{array}$ & $\begin{array}{c}\text { TVB velue } \\
(\mathbf{m g} / \mathbf{1 0 0} \text { g) }\end{array}$ & pH velue \\
\hline \multirow{4}{*}{ KA_24 } & 0 & $3.15 \pm 0.15 \mathrm{~A}$ & $8.33 \pm 0.30 \mathrm{~A}$ & $4.35 \pm 0.15 \mathrm{~B}$ \\
\cline { 2 - 5 } & 1 & $2.29 \pm 0.18 \mathrm{~B}$ & $6.11 \pm 0.08 \mathrm{~A}$ & $6.29 \pm 0.18 \mathrm{~A}$ \\
\cline { 2 - 5 } & 2 & $2.57 \pm 0.16 \mathrm{C}$ & $6.67 \pm 0.15 \mathrm{~A}$ & $6.57 \pm 0.16 \mathrm{~A}$ \\
\cline { 2 - 5 } & 3 & $1.18 \pm 0.09 \mathrm{C}$ & $7.10 \pm 0.03 \mathrm{~A}$ & $6.18 \pm 0.09 \mathrm{~A}$ \\
\hline \multirow{4}{*}{ KA_48 } & 0 & $3.08 \pm 0.13 \mathrm{~A}$ & $6.90 \pm 0.08 \mathrm{~A}$ & $5.58 \pm 0.13 \mathrm{~A}$ \\
\cline { 2 - 5 } & 1 & $4.75 \pm 0.18 \mathrm{~A}$ & $10.55 \pm 0.44 \mathrm{~A}$ & $3.95 \pm 0.18 \mathrm{~B}$ \\
\cline { 2 - 5 } & 2 & $3.83 \pm 0.11 \mathrm{~A}$ & $8.29 \pm 0.10 \mathrm{~B}$ & $5.83 \pm 0.11 \mathrm{~A}$ \\
\cline { 2 - 5 } & 3 & $3.68 \pm 0.24 \mathrm{~A}$ & $8.87 \pm 0.16 \mathrm{~B}$ & $5.68 \pm 0.24 \mathrm{~A}$ \\
\cline { 2 - 5 } & CsCC 1\% & $4.32 \pm 0.12 \mathrm{~A}$ & $9.01 \pm 0.06 \mathrm{~A}$ & $5.32 \pm 0.12 \mathrm{~A}$ \\
\hline \multirow{3}{*}{ KA_72 } & 0 & $6.58 \pm 0.16 \mathrm{~A}$ & $12.64 \pm 0.27 \mathrm{~A}$ & $2.58 \pm 0.16 \mathrm{~B}$ \\
\cline { 2 - 5 } & 1 & $4.24 \pm 0.28 \mathrm{~A}$ & $9.62 \pm 0.09 \mathrm{~B}$ & $4.24 \pm 0.28 \mathrm{~A}$ \\
\cline { 2 - 5 } & 2 & $4.14 \pm 0.11 \mathrm{~A}$ & $10.40 \pm 0.35 \mathrm{~A}$ & $5.14 \pm 0.11 \mathrm{~A}$ \\
\cline { 2 - 5 } & 3 & $3.92 \pm 0.23 \mathrm{~B}$ & $10.72 \pm 0.15 \mathrm{~A}$ & $5.92 \pm 0.23 \mathrm{~A}$ \\
\cline { 2 - 5 } & $\mathrm{CsCC} 1 \%$ & $5.18 \pm 0.06 \mathrm{~A}$ & $11.83 \pm 0.28 \mathrm{~A}$ & $4.18 \pm 0.06 \mathrm{~A}$ \\
\hline
\end{tabular}

The values followed by the same letter are not distinct from each other $(\alpha=0.05)$ 
Table 4. The value of favorite edible coating of tuna (KA) using chitosan nanoparticle concentration with long storage time

\begin{tabular}{|c|c|c|c|c|}
\hline \multirow{2}{*}{$\begin{array}{l}\text { Length of storage } \\
\text { (hours) }\end{array}$} & \multirow{2}{*}{$\begin{array}{c}\text { Concentration } \\
\text { of CsCC NPs } \\
(\%)\end{array}$} & \multicolumn{3}{|c|}{ Tingkat Kesukaan } \\
\hline & & Elasticity & Color & Flavor \\
\hline \multirow{5}{*}{ KA_24 } & 0 & $4.04 \mathrm{~B}$ & $4.25 \mathrm{~B}$ & $4.15 \mathrm{~B}$ \\
\hline & 1 & $4.42 \mathrm{~B}$ & $4.16 \mathrm{~B}$ & $4.29 \mathrm{~B}$ \\
\hline & 2 & $4.46 \mathrm{~B}$ & $4.68 \mathrm{~B}$ & $4.57 \mathrm{~B}$ \\
\hline & 3 & $5.11 \mathrm{~A}$ & $5.24 \mathrm{~A}$ & $5.18 \mathrm{~A}$ \\
\hline & CsCC $1 \%$ & $6.67 \mathrm{~A}$ & $6.48 \mathrm{~A}$ & $6.58 \mathrm{~A}$ \\
\hline \multirow{5}{*}{ KA_48 } & 0 & $4.88 \mathrm{~B}$ & $4.62 \mathrm{~B}$ & $4.75 \mathrm{~A}$ \\
\hline & 1 & $4.90 \mathrm{~B}$ & $4.75 \mathrm{~B}$ & $4.83 \mathrm{~A}$ \\
\hline & 2 & $4.85 \mathrm{~B}$ & $4.51 \mathrm{~B}$ & $4.68 \mathrm{~A}$ \\
\hline & 3 & $5.23 \mathrm{~A}$ & $5.4 \mathrm{~A}$ & $5.32 \mathrm{~A}$ \\
\hline & $\mathrm{CsCC} 1 \%$ & $6.8 \mathrm{~A}$ & $6.65 \mathrm{~A}$ & $6.73 \mathrm{~A}$ \\
\hline \multirow{5}{*}{ KA_72 } & 0 & $5.47 \mathrm{~A}$ & $5.69 \mathrm{~A}$ & $5.58 \mathrm{~A}$ \\
\hline & 1 & $5.43 \mathrm{~A}$ & $5.04 \mathrm{~A}$ & $5.24 \mathrm{~A}$ \\
\hline & 2 & $5.22 \mathrm{~A}$ & $5.06 \mathrm{~A}$ & $5.14 \mathrm{~A}$ \\
\hline & 3 & $6.08 \mathrm{~A}$ & $5.76 \mathrm{~A}$ & $5.92 \mathrm{~A}$ \\
\hline & CsCC $1 \%$ & $4.25 \mathrm{~B}$ & $4.25 \mathrm{~B}$ & $4.25 \mathrm{~B}$ \\
\hline
\end{tabular}

The values followed by the same letter are not distinct from each other $(\alpha=0.05)$

\subsection{3. $p H$}

Table 3 shows the measurement of acidity level by determining the $\mathrm{pH}$ value in the observation of the edible coating of smoked fish using biopolymer concentrations of NPs CsCC 0, 1, 2, $3(\% \mathrm{w} / \mathrm{v})$ and CsCC 1 (\% v/v), the average $\mathrm{pH}$ value of tuna smoked fish with 24 hour observation time (KA-24) each is $4.39-6.57$. While the median value of observations of 48 hours (KA-48) respectively is $3.95-5.58$. Furthermore, the median value of observations of 72 hours (KA-72) respectively is $2.58-$ 5.92. The results of the printing $(\alpha=0.05)$ of the $\mathrm{pH}$ value of tuna smoked fish showed that the addition of NPs CsCC suspension biopolymer in the edible coating formula affects the value of $\mathrm{pH}$. While further testing shows that on long observations during storage KA-24 and KA-48 at room temperature, the $\mathrm{pH}$ value of tuna smoked fish that is given the treatment of edible coatings NPs CsCC concentration 1,2 and $3(\%$ w/v) with a different observation length higher $\mathrm{pH}$ value compared to the use of NPs CsCC $0 \%$ and CsCC $1 \%$. This is because of the existence of polymer chitosan in production into NPs CsCC with the method of beads-milling in an edible coating formula that helps inhibit the growth of lactic acid bacteria and maintain the $\mathrm{pH}$ value of tuna smoked fish. The results of previous research using edible coating treatment of chitosan are absolutely noticeable in the increase of $\mathrm{pH}$ value by increasing the length of storage from $\mathrm{pH} 5.00$ to 5.65 [7].

\subsubsection{Favorite Level Test}

Antimicrobial components contained in the edible coating of biopolymer NPs CsCC and chitosan $\mathrm{CC}$ are able to retain the color, elasticity, and flavor of the tuna smoked fish during the storage period 24, 48 and 72 hours. There are several things that cause the change of organoleptic properties in fish in addition to storage time, fish raw material that is easily damaged, as well as the mechanical process in the handling of materials is the process of dyeing the fish on the suspension NPs CsCC that has a different time vulnerable and the provision of heat in each biopolymer NPs CsCC. Duration of storage, quality parameters such as elasticity, color, taste and so on will change due to environmental influences such as temperature, humidity and air pressure or because of the food composition factor itself [7].

\section{CONCLUSIONS}

The use of chitosan nanoparticles as edible coating can serve as active packaging and able to maintain the quality of fishery products. This is evident from the formula of using the concentration of coconut crab nanoparticles (NPs CsCC) and the duration of observations as follows;

- The addition of $2(\% \mathrm{w} / \mathrm{v})$ nanoparticles on the fish coating fresh tuna fillets can meet the SNI standard (12 hour observation time).

- The addition of $3(\% \mathrm{w} / \mathrm{v})$ nanoparticles in the fish coating the filet smoked tuna can meet the SNI standard (observation time 72 hours). 


\section{ACKNOWLEDGMENT}

This research is fully supported by the scholarship funds of the Government of Indonesia through the Indonesian Institute of Education Scholarship Fund Management Institution (LPDP BUDI-DN) Indonesia. Number: PRJ4952/LPDP.3/2016.

\section{REFERENCES}

[1] Duran A, Erdemli U, Karakaya M, Yilmaz MT. 2008. Effects of slaughter methods on physical, biochemical and mirobiological quality of rainbow trout Oncorhynchus mukiss and mirror carp Cyprinus carpio filleted in pre-, in- or postrigor periods. Fish. Science 1146-1156.

[2] Regalado C, Perez-Perez C, Lara-Cortes E, Gracia-Almendarez B. 2006. Whey protein based edible food packaging films and coating. Agricultural and Food Biotechnology. Pp. 237261.

[3] Pranoto, Y., V.M. Salokhe, and S.K. Rakshit. 2005. Physical and antibacterial properties of alginate-based edible film incorporated with garlic oil. J. Food Res. Intl. 38: 267-272.

[4] Rojas-Grau, M.A., R. Soliva-Fortuny, and O. Martin-Belloso. 2009. Edible coating as corrier to active ingredients for fresh cut fruit. In The World of Food Science. www.worldfoodscience.org/cms/?pid=1005154 [3 Januari 2019].

[5] Sorrentino A, G Gorrasi, V Vittoria. 2007. Potential perspectives of bionanocomposites for food packaging applications. Trends Food Sci. Technol. 18: 84-95.

[6] Tapilatu, Y., Nugraheni, P.S., Ginzel, T., Latumahina, M., Limmon, G.V. and Budhijanto, W., 2016. Nano-chitosan utilization for fresh yellowfin tuna preservation. Aquatic Procedia, 7 , pp.285-295.

[7] Renur, N.M., Haryadi, Y., Darmawati, E. and Kapelle, I.B.D., 2016. Application of Chitosan and Chinese Lemon Extract (Citrus Mitis) Based
Edible Coating on Tuna Fillet. Journal of Food and Nutrition Sciences, 4(2), p.29.

[8] Mailoa, M.N., Tapotubun, A.M. and Matrutty, T.E., 2017, October. Analysis Total Plate Counte (TPC) On Fresh Steak Tuna Applications Edible Coating Caulerpa sp During Stored at Chilling Temperature. In IOP Conference Series: Earth and Environmental Science (Vol. 89, No. 1, p. 012014). IOP Publishing.

[9] Komariah, Wulansari N, Harmayanti W. 2013. Efektivitas kitosan dengan derajat deasetilasi dan konsentrasi berbeda dalam menghambat pertumbuhan bakteri garam negatif (Pseudomonas aeruginosa) dan garam positif (Staphylococus auteus) rongga mulut. Siminar Nasional X Pendidikan Biologi. Fakultas Kedokteran Gigi. Univeritas Trisakti.

[10] Fardiaz S. 1992. Mikrociologi Pengolahan I. Bogor (ID): Pusat Antar Universitas Pangan dan Gizi IPB.

[11] Suptijah, P., Jacoeb, A.M. and Rachmania, D., 2011. Karakterisasi nano kitosan cangkang udang vannamei (Litopenaeus vannamei) dengan metode gelasi ionik. Jurnal Pengolahan Hasil Perikanan Indonesia, 14(2)

[12] Yanti AR, Rochima E. 2009. Pengaruh Suhu Pengeringan terhadap Karakteristik Kimiawi Filet Lele Dumbo Asap Cair pada Penyimpanan Suhu Ruang. J. Bionatura. 11:21-36.

[13] Rasulu, H., Praseptiangga, D., Joni, I.M. and Ramelan, A.H., Preparation and Characterization of Biopolymer Chitosan Nanofiber from Coconut Crab Shell. International Journal on Advanced Science, Engineering and Information Technology. Vol.9 (2019) No. 3. pp.866-873.

[14] Yasni S, Elisabeth Y, Syamsir E, Parhusip A. 2004. Produksi Senayan. Antimikroba dari Mobe dan Aplikasinya sebagai Bahan Pengawet Pangan. J. Mikrobial. Indones. (9) 2:68-72.

[15] Hadi HNSS. 2008. Aplikasi kitosan dengan penambahan ekstrak bawang putih sebagai pengawet dan edible coating bakso sapi [tesis]. Bogor (ID). Institut Pertanian Bogor. 